\title{
WATER SuPPLY RESOURCES AND MANAGEMENT PRACTICES IN SARAWAK AND OTHER COUNTRIES
}

\author{
Nur Rasfina Mahyan ${ }^{1}$ and Onni Suhaiza Selaman ${ }^{2}$ \\ 1 Centre for Pre-University Studies, Universiti Malaysia Sarawak, 94300 Kota Samarahan \\ 2 Department of Civil Engineering' Faculty of Engineering, Universiti Malaysia Sarawak, 94300 Kota Samarahan
}

Date received: 25/07/2016, Date accepted: 08/09/2016

Corresponding author's email: mnrasfina@unimas.my

\begin{abstract}
The rapid urbanization faced by Sarawak has raised the concern on whether the current water supply is adequate to cater for the increasing demands in future. This study focuses on identifying the potential options of water supply resources and management practices for Sarawak in future. The water supply resources and management practices from other countries are reviewed as to provide guidance for Sarawak in improving their water supply resources and management practices. The desk study is performed by collecting data and information from existing resources such as internet, government agencies, journal papers, and published reports. In this study, five types of water resources were considered to be used by studied countries including surface water, groundwater, desalinated water, rainwater and reclaimed water. The usage of surface water is recorded as the highest among all resources for both in Sarawak and other countries. In terms of water storage system, the difference between Sarawak and other countries are not significant as they adopted almost the similar systems such as reservoir and well. Ideally, there are three proposed potential options regarding water supply resources for Sarawak in future namely rainwater harvesting, desalinated water and reclaimed water. Nonetheless, most of the management practices in other countries had already been practiced by Sarawak itself but may differ in terms of technologies and method of applications. Thus, effective water resources management must be supported by understanding of the availability of the resource itself in order to address the probable challenges in future.
\end{abstract}

Keywords: urbanization, water resources, surface water, management practices, method of applications

\subsection{INTRODUCTION}

$\mathrm{K}^{\mathrm{v}}$ UCHING Water Supply System was recorded as the earliest water supply system in Sarawak. The water supply was obtained from a nearby stream which provides about 100,000 gallons per day of water for 8,000 consumers, out of 25,000 of the total populations in 1887. In January 1959, Kuching Water Board (KWB) and Sibu Water Board (SWB) were established. The management of water supply systems in Kuching and Sibu towns were taken by KWB and SWB respectively from Jabatan Kerja Raya (JKR). The State Government of Sarawak establishes a company namely LAKU Management Sdn. Bhd., in January 1996 which responsible in managing three water supply authorities which is Miri, Bintulu and Limbang. Apart from that, JKR Sarawak continues to perform the function and responsibilities of developing and administering water supplies in the other areas of Sarawak especially in the rural area [1].

Due to population increment in Sarawak, the estimated raw and treated water are expected to increase every year. Furthermore, it is critical to make sure that the water supply is enough to fulfill the water demand of the state throughout the year, due to the occurrence of unexpected flooding during the wetter months of December to February. This research study focuses on proposing the potential options of water supply resources and management practices for Sarawak in future. 
The treated water in the state of Sarawak is supplied by KWB, SWB, LAKU Management Sdn. Bhd. and Public Works Department Sarawak. KWB supplies water to the Kuching City areas, SWB to Sibu town, LAKU Management Sdn. Bhd. to the town of Bintulu, Miri and Limbang. The Public Works Department Sarawak through its Water Supply Branch is responsible for the supply of treated water to areas in Sarawak where treated water is not being supplied by Water Supply Agencies [2]. The area of supply by Sarawak Water Authority is shown in Figure 1.

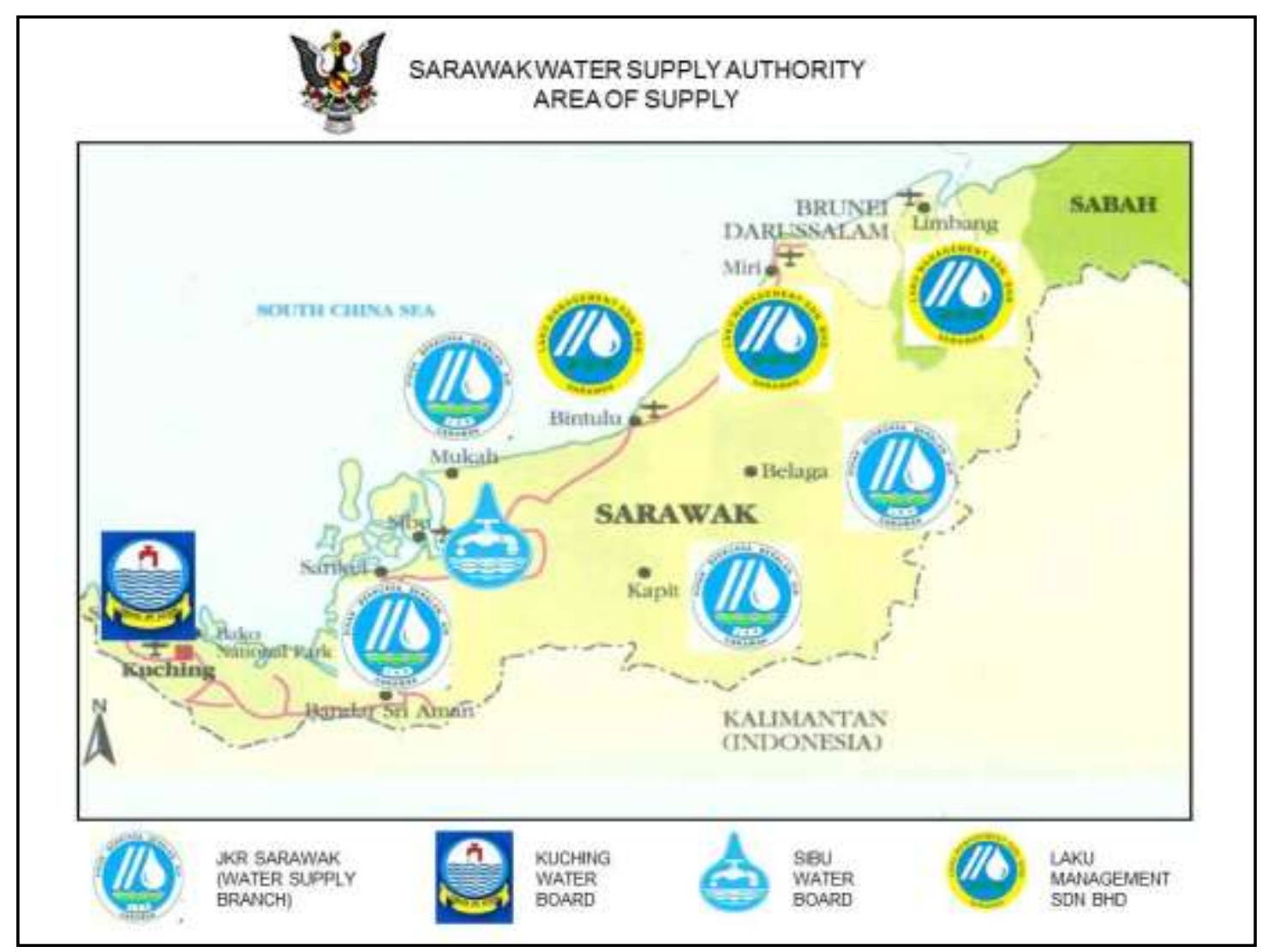

Figure 1: Area of Supply by Sarawak Water Authority

\subsection{METHODOLOGY}

In this research, the focus is on the identification of current and potential water supply resources and their management practices in Sarawak and in other countries. Thus, extensive desk study is necessary for the study. Information related to source of water supply, water storage and management practices in Sarawak and other countries are extracted from internal sources, the internet, libraries, trade associations, government agencies, and published reports. The collected data and information were then analyzed based on three main areas: source of water supply, water storage system, and management practices of water supply. The analysis involves comparison of water supply practices in Sarawak and other countries. In Sarawak, KWB, SWB, and LAKU Management Sdn. Bhd. are the water authorities which responsible to supply the treated water through the state. Other countries referred to in this study are: countries which represent the six continents (Asia, Africa, North America, South America, Europe and Australia), and countries which are categorized as rich and poor countries. Countries which represent the six continents are taken into account as different continent are affected by different types of climate and rainfall characteristics, in which, it could influence the water resources availability and its water supply management practices. Top richest and top poorest countries based on world ranking are taken into account as the variation of economic condition in those countries might influence the 
choice of source of water supply and its management practices. The analyses are expected to give further insight on the potential options for Sarawak's future water supply resources and management practices.

\subsection{RESULTS AND DISCUSSIONS}

\subsection{Water Supply Resources}

According to the data obtained as shown in Table 1, it showed that surface water is at the top of ranking for both in Sarawak and other studied countries for water supply resources category. Most of the countries used surface water as it is essential natural resource that can be used for many purposes and naturally replenished by precipitation.

Meanwhile, Sarawak and other countries selected groundwater as the next selection for water supply resource. In fact, groundwater is often cheaper and less vulnerable to pollution as it is tapped through wells that placed in water-bearing soils and rocks.

In other countries such as Egypt, Qatar and Singapore, they used desalinated water in order to allow people to have access to water that was previously not potable. For the case in Sarawak, five out of eight water treatment plants under the Saltwater Desalination Programme of 1 Malaysia Development Berhad Foundation has been implemented [6].

In the meantime, two studied countries such as India and Colombia practicing rainwater harvesting system for non-consumptive purposes in order to reduce the need for potable water supply. However, in Sarawak, the rainwater harvesting serves as a secondary water supply system to the existing water supply in Bair Long House by collecting and distributing rainwater to the longhouse [7].

Other than that, the top richest countries involving Qatar and Singapore used highly treated wastewater as drinking water and some commercial uses. The wastewater are treated up to quaternary level of potable water quality by using hyperfiltration or known as reverse osmosis process.

Table 1: Water Supply Resources in Sarawak and Other Countries

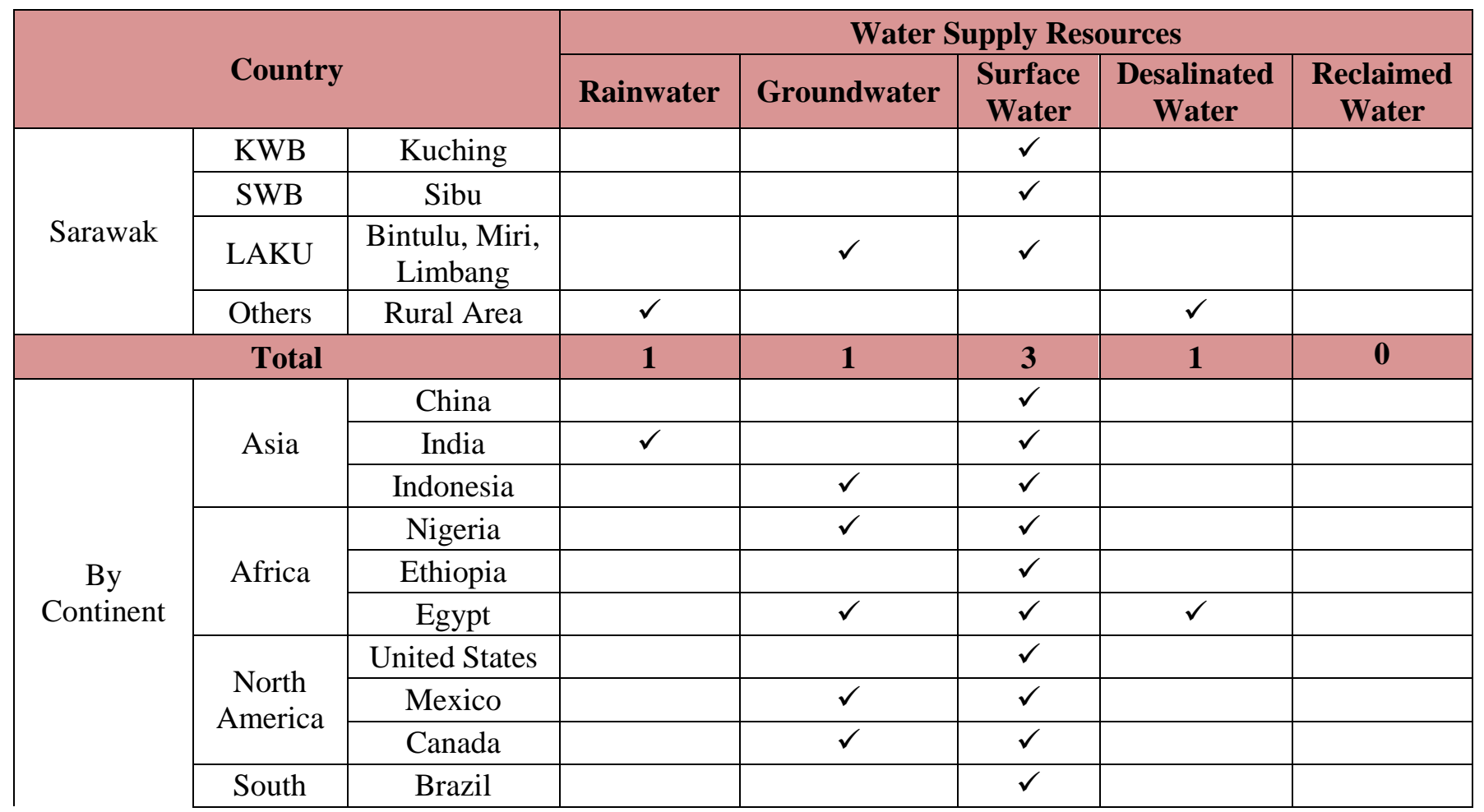




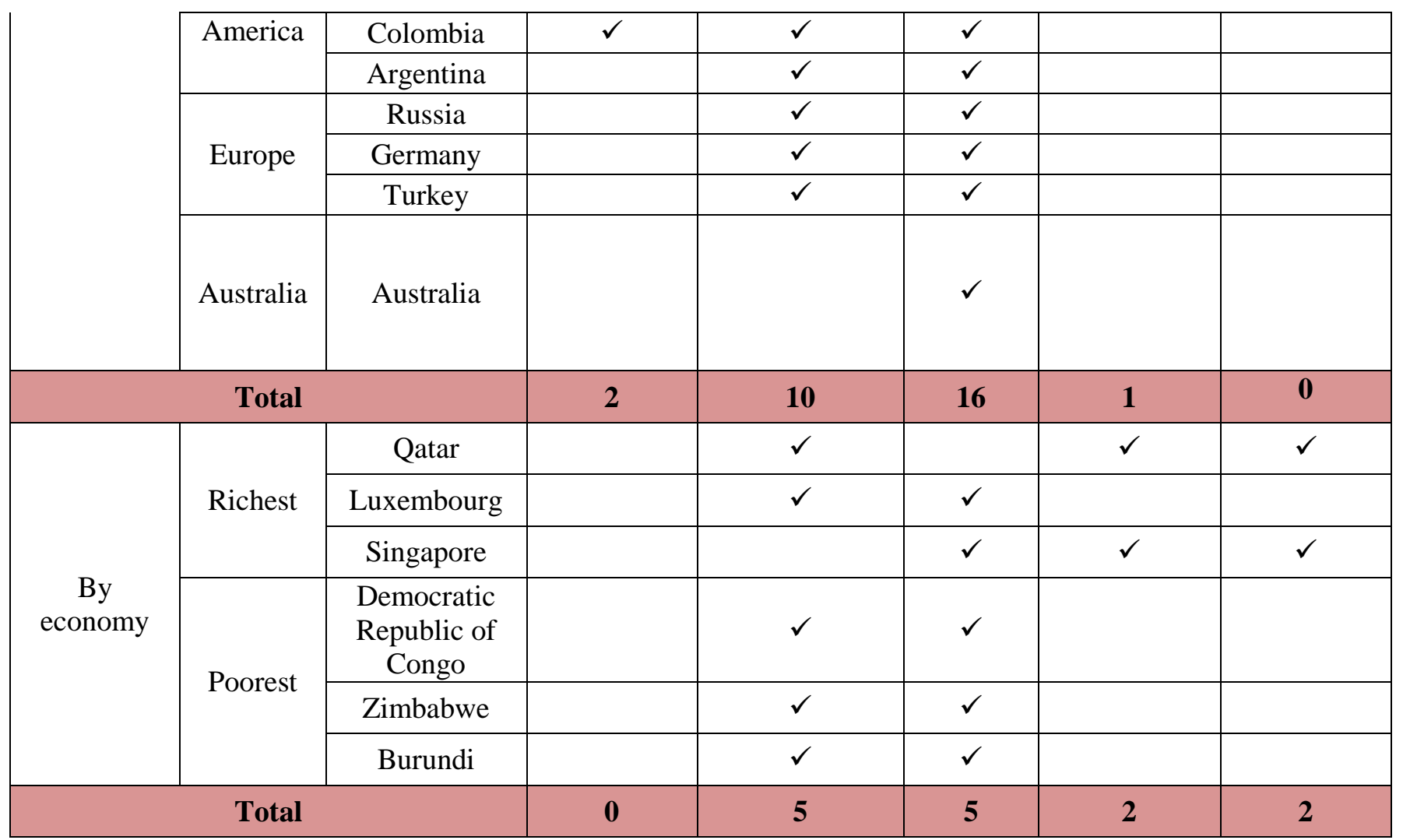

\subsection{Water Storage System}

In terms of water storage system as shown in Table 2, the difference between Sarawak and other studied countries are not significant as they adopted almost the similar systems such as reservoir, well and rainwater harvesting. Although the similar systems adopted, there will be difference in terms of capacities and technologies used by the studied countries. Thus, such a good technologies practiced by other countries can give guidance to Sarawak in order to improve Sarawak's water storage system in future.

Table 2: Water Storage System in Sarawak and Other Countries

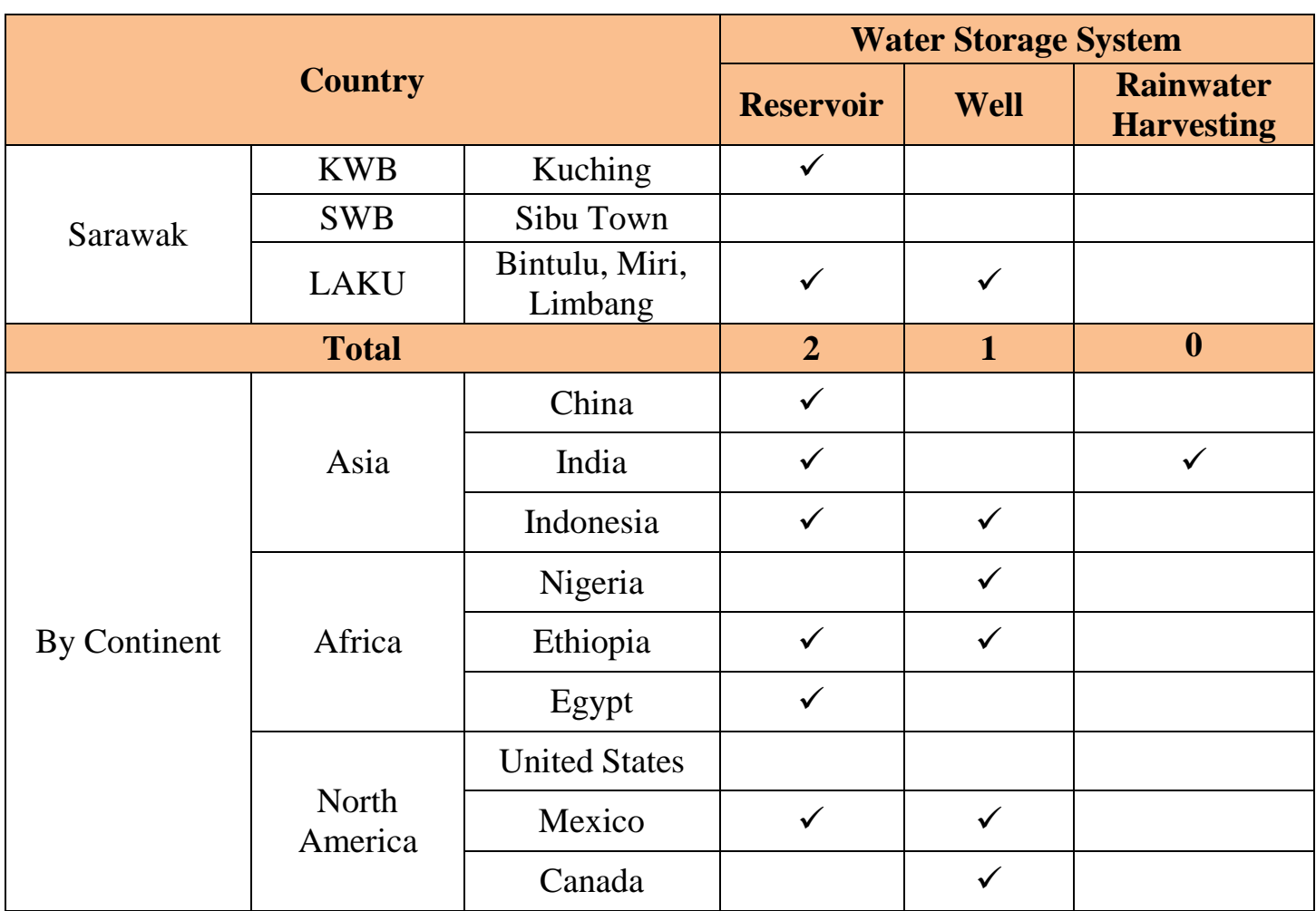




\begin{tabular}{|c|c|c|c|c|c|}
\hline & \multirow{3}{*}{$\begin{array}{c}\text { South } \\
\text { America }\end{array}$} & Brazil & $\checkmark$ & & \\
\hline & & Colombia & & $\checkmark$ & $\checkmark$ \\
\hline & & Argentina & & & \\
\hline & \multirow{3}{*}{ Europe } & Russia & $\checkmark$ & & \\
\hline & & Germany & & & \\
\hline & & Turkey & $\checkmark$ & & \\
\hline & Australia & Australia & $\checkmark$ & & \\
\hline \multicolumn{3}{|c|}{ Total } & 10 & 6 & 2 \\
\hline \multirow{6}{*}{ By Economy } & \multirow{3}{*}{ Richest } & Qatar & & $\checkmark$ & \\
\hline & & Luxembourg & $\checkmark$ & $\checkmark$ & \\
\hline & & Singapore & $\checkmark$ & & \\
\hline & \multirow{3}{*}{ Poorest } & DRC & & & \\
\hline & & Zimbabwe & $\checkmark$ & $\checkmark$ & \\
\hline & & Burundi & & & \\
\hline \multicolumn{3}{|c|}{ Total } & 3 & 3 & $\mathbf{0}$ \\
\hline
\end{tabular}

Considering all of the features, Sarawak has capable in improving their existing rainwater harvesting system and widening the area of supply as many researchers has conducted a lot of research study on the potential of rainwater harvesting throughout the state of Sarawak. This system has been recognized as an alternative water supply in future and had potential to be implemented in Sarawak since Sarawak received high rainfall intensity. Currently, the rainwater harvesting in Sarawak is only implemented in rural areas as it has poor accessibility to the area to supply piped water. The rainwater harvesting system in the Bair Long House, Betong, Sarawak serves as a secondary water supply system to the existing water supply in the longhouse [7]. In meantime, the water solution project in Pulau Bruit focuses on rainwater harvesting system for four villages which can store up to 40,000 litres for each platform [8].

Furthermore, Sarawak also has a great potential in discovering the desalinated water as alternative source of water supply for future, especially in coastal area. To date, five out of eight water treatment plants under the Saltwater Desalination Program of 1Malaysia Development Berhad Foundation has been implemented in eight areas in Sarawak to provide treatment on the water source that was salty [6].

By referring to the top richest countries like Qatar and Singapore who succeeded in turning wastewater into high-grade reclaimed water, Sarawak can also use reclaimed water as source of water supply in future. In fact, the modern technologies such as ultraviolet disinfection and reverse osmosis are commonly used when reclaimed water is mixed with the potable water supply before consumption is permitted. For the time being, Sarawak had an initiative in treating their wastewater for reuse as secondary sources of water for non-consumptive purposes. The treated wastewater has been used for flushing toilet, for watering the garden and for cleaning purposes.

\subsection{Water Management Practices}

Based on data presented as shown in Table 3, most of the water management practices in other countries had already been practiced in Sarawak itself by the State Water Authority. For example, monitoring the leakages of piping system and improving the quality of distributed water supply to the users. However, the practices in managing water issues in Sarawak and other countries may differ in terms of technologies and method of applications. In Singapore which categorized as a rich country, they used an advancement technology and cheaper prices of membrane to produce the desalinated 
water as a source of water supply. According to Indonesia's management practices, it is suggested that purchasing water from water kiosks where the kiosks are placed in areas where people face difficulties in obtaining fresh water. Furthermore, the water governance of Indonesia had rising their water tariff since low water tariff is one of the causes to the exceeding water demand [9]. Other than that, Sarawak can also raise concerns about water security which means reliable access to safe water at an affordable price [10] among the communities of Sarawak. This can be learned from other countries where the situation is almost the same which might be faced by Sarawak in future as well if not addressed at an early stage.

Table 3: List of Water Management Practices

\begin{tabular}{|c|c|c|}
\hline \multicolumn{2}{|c|}{ Countries } & Management Practices \\
\hline \multirow[t]{2}{*}{ Sarawak } & Kuching & $\begin{array}{l}\text { - Upgrading and retrofitting works at Matang Treatment Plant to sustain its } \\
\text { reliability [3]. } \\
\text { An annual water main flushing programme was introduced to improve } \\
\text { the quality of water [3]. } \\
\text { - Leakage Control Zones had been set up within Kuching Water Board } \\
\text { Supply Network to monitor the leakage level [3]. } \\
\text { "Friends of KWB" programme is to help achieve earlier detection and } \\
\text { repair of leakages [3]. }\end{array}$ \\
\hline & Sibu & $\begin{array}{l}\text { - Construction of "Pemasangan Paip Utama Di Jalan Tun Ahmad Zaidi } \\
\text { Adruce" to improve the existing trunk main [4]. } \\
\text { - Upgrading of Treated Water Pumping System for } 60 \text { Meter Zone Project } \\
\text { to improve the water pressure [4]. } \\
\text { - Non-Revenue Water Program focused on pressure management as high } \\
\text { pressures causing pipe leakages [4]. }\end{array}$ \\
\hline \multirow{6}{*}{ By Continent } & India & $\begin{array}{l}\text { - Meter water connection to reduce losses in terms of leakages and } \\
\text { unauthorized tapping to improve efficiency in service delivery [15]. } \\
\text { Utilized water in standby reservoir at Dimna during low water levels } \\
\text { [15]. }\end{array}$ \\
\hline & Indonesia & $\begin{array}{l}\text { - Rising water tariff since low water tariff is the prime causes to the } \\
\text { exceeding of water demand [9]. } \\
\text { People purchase water from water kiosks where these kiosks are found in } \\
\text { areas where people face difficulties in obtaining fresh water [9]. }\end{array}$ \\
\hline & Mexico & 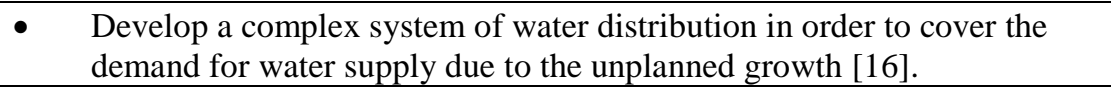 \\
\hline & Nigeria & $\begin{array}{l}\text { Households who purchase water from tanker trucks resell the water by } \\
\text { bucket to individuals who cannot afford large storage tanks or cannot be } \\
\text { reached by the tanker trucks [11]. }\end{array}$ \\
\hline & Argentina & $\begin{array}{l}\text { - Low-income customers are eligible for a subsidy for the tariff system } \\
{[12] .}\end{array}$ \\
\hline & Germany & $\begin{array}{l}\text { - The extraction and distribution systems have been modified so that water } \\
\text { demand can be adequately met at any time for the various uses [17]. }\end{array}$ \\
\hline \multirow{3}{*}{ By Economy } & Qatar & $\begin{array}{l}\text { Raised concerns about water security which means reliable access to safe } \\
\text { water at an affordable price for every person [10]. } \\
\text { Used more efficient desalting systems to minimize the carbon emission } \\
\text { due to the combustion of fossil fuels [10]. }\end{array}$ \\
\hline & Luxembourg & $\begin{array}{l}\text { - Monitor the quality of distributed water that served their populations and } \\
\text { look after the supply infrastructures [13]. }\end{array}$ \\
\hline & Singapore & $\begin{array}{l}\text { - Used advanced dual-membrane and ultraviolet technologies to produce } \\
\text { high-grade reclaimed water (branded as NEWater) on a large scale [14]. } \\
\text { Used advancement technology and cheaper membrane prices to make } \\
\text { desalinated water [14]. }\end{array}$ \\
\hline
\end{tabular}

\subsection{CONCLUSIONS}

Based on the data obtained from the desk study, the following conclusions can be drawn: 
i. Five types of water supply resources such as surface water, groundwater, desalinated water, rainwater and reclaimed water were used by studied countries.

ii. The usage of surface water as water resource is the highest of all for both in Sarawak and other countries.

iii. In terms of water storage system, three common systems had been practiced by studied countries namely reservoir, well, rainwater harvesting system.

iv. The difference between Sarawak and other countries in terms of water storage system are not significant as they adopted almost the similar systems but differ in terms of capacities and technologies used.

v. Three proposed options regarding water supply resources for Sarawak in future namely rainwater harvesting, desalinated water and reclaimed water.

vi. Most of the water management practices in other countries had been practiced in Sarawak itself but differ in terms of technologies and method of applications.

\section{REFERENCES}

[1] Shariff, G. (April, 2003). Rakan Sarawak. Retrieved 15 September, 2014, from SarawakNet: http://www.sarawak.com.my/info/rakansarawak/042003/specialfocus/index.shtm

[2] National Audit Department of Malaysia, NADM (2013). The Activities Of Ministries/Departments/Agencies And Management Of State Government's Companies for Sarawak.

[3] Kuching Water Board. (2011). Kuching Water Board Annual Report. Kuching: Auditor General Malaysia.

[4] Sibu Water Board. (2012). Sibu Water Board Annual Report. Sibu: Auditor General Malaysia.

[5] LAKU Management, Sdn. Bhd. (11 August, 2015). About Us: LAKU Management Sdn. Bhd. Retrieved July, 2015, from http://www.lakumanagement.com.my

[6] Nawawi, A. (7 June, 2013). Five 1MDB Foundation's Projects Completed. Retrieved from New Sarawak Tribune: http://www.newsarawaktribune.com

[7] NAHRIM. (2 April, 2011). The Officiating Ceremony Of Rainwater Harvesting System (SPAH) At Bair Long House, Betong, Sarawak. Retrieved from Official Website of Ministry of Natural Resources and Environment: http://www.nahrim.gov.my/

[8] Yayasan Sejahtera. (9 August, 2014). Water Solutions For 4 Villages in Pulau Bruit, Sarawak. Retrieved from SEJAHTERA Building Sustainable Communities: http://www.sejahtera.my/category/completed-projects

[9] Hadipuro, W., \& Indriyanti, N. (2009). A typical urban water supply provision in developing countries: A case study of Semarang City, Indonesia. Water Policy 11(1), 55-66.

[10] Darwish, M., \& Rabi, M. (8 June, 2012). Qatar water challenges. pp. 32-44.

[11] Ishaku, J. M. (2011). Assessment of groundwater quality index for Northestern Nigeria. Journal of geology and mining research, 3(9), 219-231.

[12] Garzon, C., Campos, S., Machado, K., Birolo, N., Centeno, C., Jimene, J., \& Nuques, C. (2009). Water and Sanitation Program for the Buenos Aires Metropolitan Area and Conurbation. Buenos Aires: Inter-American Development Bank Loan Proposal.

[13] Tom, L. (2 September, 2005). Distribution Of Drinking Water In The Grand-Duchy Of Luxembourg - The Challenge To Mix Water Of Different Chemical And Physical Properties. pp. 201-236.

[14] Kheong, T. C. (14 April, 2010). Learning From Good Practices in Eight Asian Cities. pp. 90-121.

[15] Basu, G., \& Mahadev, H. (2008). Continuous Water Supply: A Case Study from Jamshedpur. Mumbai: Indian Water Works Association's

[16] Tortajada, C. (June, 2006). Water Management in Mexico City Metropolitan Area. International Journal of Water Resources Development (Impact Factor: 0.9). 06/2006; 22(2), 353-376..

[17] Bartel, H. (2010). Water Resource Management in Germany. Germany: Federal Environment Agency (UBA). 